\title{
TACITUS' ACCOUNT OF THE PANNONIAN REVOLT (ANN. 1.16-30)
}

\author{
Annemaré Kotzé (University of Stellenbosch)
}

\section{Introduction}

The Pannonian revolt (Ann. 1.16-30) is one of the sections that receives the least attention in the prolific body of criticism on the first six books of the Annales. This results partly from the bipartite structure of the Tiberian hexad which invites critics-once they have dealt with the prologue $(1.1-15)^{1}-$ to concentrate on Germanicus as the foil for Tiberius in the first triad (1.31ff) and on Seianus in the second. However, the main reason for the lack of interest is probably that, in spite of Leeman's excellent discussion (1974:368-377) of capita 16 to 30, the view expressed in F.R.D. Goodyear's commentary (1972:195) still looms large in critical perceptions of Tacitus' description of the revolt in Pannonia:

T. seems explicitly to separate them [the mutinies] from events in Rome ... a procedure through which artistic convenience may have got the better of historical truth, since it is at least a real possibility that uncertainty over the outcome of the mutinies prolonged Tiberius' doubts and hesitations over the succession.

This criticism from Goodyear is complemented by attempts by others to prove Tiberius' prior knowlege of the mutinies and Tacitus' lack of historical accuracy or insight which led him to overlook such an important factor. ${ }^{2}$ The common notion that the scope of Tacitus' treatment of the Pannonian mutiny exceeds its importance falls into the same category. ${ }^{3}$

It is the aim of this article to show that neither the criticism nor the relative neglect of Ann. 1.16-30 is justified. The passage demonstrates Tacitus' talents as narrator and illustrates interesting aspects of his conception of history but it is also much more. I find in it the perfect marriage of form and content one would expect from one of Rome's greatest rhetoricians in the initial chapters of his magnum opus. I shall deal first with the problems critics have with this passage and then make a few suggestions as to why I think Tacitus is justified in giving such prominence to the Pannonian mutiny at the outset of the Annales.

\footnotetext{
1 See Leeman's arguments (1973) for regarding the whole of I.1-15 as the prologue to the Annales.

2 See e.g. Schmitt 1958.

3 See e.g. Goodyear 1972:194-195.
} 


\section{Problems with Tacitus' account of the events in Pannonia}

\subsection{The mutiny and Tiberius' hesitance}

The problem Goodyear and others have is that, while the account of the Pannonian revolt is a brilliant and entertaining narrative which excellently meets the requirement of variatio and displays Tacitus' rhetorical and dramatic talents to the full, the historical significance of the event itself does not merit the effort lavished on it. What is more, the one aspect of the mutiny which they see as historically significant, is ignored by Tacitus. I cannot agree and, like Leeman (1974:372), can only say: "Dit is een 'verklaring' die ik in het geval van een historicus van Tacitus' niveau weiger te accepteren."

The relation between the Pannonian revolt and Tiberius' hesitance when addressing the senate which Goodyear and others think should have been indicated simply cannot exist in Tacitus' account. Even if modern historians were better able to evaluate the motives of the historical person Tiberius than Tacitus was, they cannot disregard the implications inherent in the recognition of ancient historiography as a literary genre. ${ }^{4}$ The Tiberius we meet through the narrative of the Annales is a character construct created by the narrator and should be consistent only with himself and his role within the narrative. A careful reading of 1.7 will make clear that this Tiberius has already taken over the principate: he has made all the right military moves. If there is any hesitation in his behaviour it cannot be because he is not sure whether to take command of the empire. In 1.7.3 the narrator says Tiberius cuncta per consules incipiebat tamquam vetere re publica et ambiguus imperandi..$^{5} \mathrm{He}$ is not saying that Tiberius was unsure as to whether he should succeed Augustus but only that he was acting as though hesitant. 6 Although the tamquam pertains directly to the ablative absolute following it, the fact that the next phrase is joined to the previous by et, makes it difficult not to carry the force of tamquam forward into the second phrase: tamquam ambiguus imperandi.

But even if this had not been the case, in 1.7.5 the narrator evaluates the actions of Tiberius he has just described and leaves the reader in no doubt as to what (in his opinion) the real state of affairs was:

sed defuncto Augusto signum praetoriis cohortibus ut imperator dederat; excubiae, arma, cetera aulae; miles in forum, miles in curiam comitabatur. Litteras ad exercitus tamquam adepto principatu misit, nusquam cunctabundus nisi cum in senatu loqueretur.

4 For a discussion of the implications of recognizing ancient historiograpy as a literary genre in the full sense of the word, see Kotze 1990:7-14.

5 References are to the Teubner text (1983).

6 Miller (1959:118) says in this regard: "Hypocrisy is a possible explanation of his behaviour, but natural diffidence and a desire to act correctly are much more probable ones." 
(But at the death of Augustus he gave the praetorian cohort the watchword as imperator. He had a guard, armed protection, all the trappings. Soldiers accompanied him to the forum and to the senate house. He sent letters to the legions as if he had taken over the principate. He was never hesitant except when he spoke to the senate.)

The narrator wants to make sure that his readers realize that in all other instances Tiberius had acted tamquam adepto principatu: he stresses that the uncertain behaviour was reserved only for his dealings with the senate. ${ }^{7}$ It must be conceded that the hesitation in the senate house indicates nothing more than Tiberius' desire to play the game of dissimulatio that he had seen his predecessor play with such great success. ${ }^{8}$ In the military sphere there was never any hesitation which could have been influenced by a military revolt in Pannonia.

\subsection{The disjunctive nature of the first two sections}

It has been shown above that in Tacitus' account there can be no relation between Tiberius' hesitance and the Pannonian mutiny. But the account of the mutiny is not completely isolated from the account of events in Rome. Tacitus does not explicitly state any connection between $1.1-15$ and 1.16-30, but the reader has been warned already in 1.1 that meaning in the Annales will derive from more indirect strategies than explicit commentary by the narrator. ${ }^{9}$ There are subtle indications which show the two sections, 1.1-15 and 1.16-30, to be mutually dependent.

The reader who comes to Tacitus' description of the revolt in Pannonia still under the impression of the atmosphere of heavy gloom and oppressiveness which pervaded chapters 1-15, cannot but be struck by the complete change in tone and atmosphere he perceives here. The reaction of the legions in Pannonia (words and deeds) in the face of mutatus princeps is irrepressible, uninhibited and explosive. Feelings surge to the surface. This stands in direct contrast to what has gone before: the adulatio and servitium in Rome, which have been the Leitmotiv of 1.1-15, reflect exactly the opposite reaction. There everything went under the surface, to be covered underneath the facade of the principate, and the prime motivation behind all words and actions was unus metus si intellegere viderentur. It is especially this strong and direct contrast but also the symmetry (15 chapters each) and parallelism (the events are to a large degree contemporaneous) of the two sections which invite comparison and imply connections which the surface meaning does not make obvious. That Tacitus intends his readers to see $1.16-30$ as further comment on what has been said in the previous section is also supported by the verbal echoes of 1.115 in 1.16-30 (see discussion below).

See also Von Albrecht 1988:60-61.

Contra Schmitt 1958:382.

See McCulloch's remark (1991:2946) on the opening line of the Annales, where he calls Tacitus "the great dissimulator." See also my own analysis (1990:48) of 1.1 and Von Albrecht 1988:63:

"Tacitus scheut direkte Stellungnahmen." 


\subsection{The excessive scope of the treatment of the Pannonian revolt}

Opinions about the excessive scope of the treatment of the revolt in 1.16-30 also stem from approaches that do not make adequate allowance for the literary character of the genre of ancient historiography. It is this kind of approach that prevents critics from asking the right question about the scope of the narration in the Pannonian section, namely: if an ancient historian in Tacitus' league gives such prominence to an apparently trivial event like the Pannonian revolt, what is his purpose? What is the historical judgement embodied in this procedure?

This would open the way to see that first, it is chronologically and thematically appropriate for Tacitus to turn to the reaction of the soldiers in Pannonia on Augustus' death after his description of the beginning of Tiberius' reign and the effect of this on the senate in Rome. A comparison between two sets of reactions, one among mostly the upper classes in Rome and the other among the rabble in the armies far from Rome, would already justify allotting more space to the event than would be required by a mere factual account. Further, one must consider the possibility of Tacitus' using the revolt as an exemplum to make a rhetorical point. 10 This means that the discerning reader should not let himself be dazzled by the brilliance of the narrative, but should carefully extract the historical judgement the author has chosen to imbed in the dramatic presentation. But the more important factor that justifies the scope of the treatment is the fact that the revolt can be seen as a first manifestation of what was to happen in 69 , events which had a profound influence on Tacitus' thinking.

\section{The Pannonian revolt: its prominence justified?}

\subsection{The background: A.D. 69}

Any attempt to understand the events described in Ann. 1.16-30 and their significance for the Annales as a whole must fully take into account the influence that we know the events of A.D. 69 had on the author of the Historiae. McCulloch (1991:2928) reminds us: "The chaos and destruction that beset the world in A.D. 69-the wanton violence, the corruption of the armies, the very burning of the Capitoline temple-exercised the single most important influence on Tacitus' conception of history." 11 And Martin (1990:1519) says: "It is not perhaps surprising that the author who had written evolgato imperii arcano posse principem alibi quam Romae fieri should turn an attentive eye to what was happening among the provincial armies at the crucial moment of the death of the first princeps." This

10 Leeman (1974:373) refers to the revolt as having "exemplarische betekenis ... voor de verhoudingen in de legers en de provincies."

11 Von Albrecht (1988:59) is another critic who feels that the influence of the year of the four Caesars is not always adequately taken into account. 
close look at the legions is not only "not perhaps surprising" but really what the informed reader should expect, part of an effort by Tacitus to get to the root of the problem that manifested itself in A.D. 69.

There are two other important factors, closely related to the events of 69 , that help us understand why it is necessary for Tacitus to focus on the mutiny in Pannonia at this stage of the narrative. First there is the psychology of the legions, recognized by Tacitus already in the prologue to the Historiae "als wesentlichen Faktor historischer Kausalität" (Von Albrecht 1988:60) (see discussion below). The other factor concerns the gradual devolution of the central power of Rome. Von Albrecht (1988:61) speaks of the "Verlagerung der Macht von der zivilen Gewalt auf die militärische-und unter Umstanden weiter von den Befehlshabern auf die Soldateska". Tacitus has shown his awareness of this in his Historiae (Von Albrecht 1988:61). We have therefore another reason for the emphasis on events in the military sphere and in the provinces.

\subsection{The Pannonian revolt and Tacitus' views on human history}

There is another aspect of Tacitus' work as an historian which explains why the Pannonian revolt is treated so extensively, namely, Tacitus' conception of human history. This is discussed in a convincing article by Harold McCulloch (1991). The point he makes (1991:2941) and which has relevance here, centres around "Tacitus' preoccupation with understanding how historical events arise".

McCulloch (1991:2940-2941) draws our attention to Ann. 4.32 where Tacitus talks about his task as historian: "Tacitus wants to show that the tedious nature of his undertaking has value because it demonstrates how historical forces evolve from what may seem like trivial events" and "... he observes that certain individual events can precipitate the movement of major historical changes." It is clear that the Pannonian revolt is just such a (relatively) trivial event which lends itself exceedingly well to a demonstration of what the destructive force of 69 looked like in its initial, seemingly harmless, stages. McCulloch (1991:2941) says further on: "in the next chapter ... he [Tacitus] does suggest a topic of study that is particularly suitable for revealing the specific events that trigger monumental changes: the psychological makeup of those in control of government, whether they be the masses, the aristocracy, or one man." He then deduces that it is by studying the psychological motivations of Tiberius and others that Tacitus hopes "to reveal the ratio and causae that led to the upheaval in A.D. 69". I contend that it is above all by studying the psychology of the armies (as can be illustrated par excellence by an examination of the first mutiny following the death of Augustus) that Tacitus hopes to unravel the ratio and causae of all that happened in A.D. 69.

\subsection{The Pannonian revolt: information on the mens exercituum}

When Tacitus' treatment of the mutiny in Pannonia is seen as the elaboration of a specific exemplum with the purpose of examining one of the most important forces 
in the principate at the time, it becomes obvious why the scope of the treatment should be as ample as it is. Further, even though historians of today do not rate the historical significance of the Pannonian revolt very high, it becomes clear that it is the exemplary character of the first reaction of legions in a province at this watershed moment in the history of the principate (mutatus princeps) which constitutes its significance within the Annales.

What then does the narrator intend to tell us about the mens exercituum? Tacitus starts this section by using the same technique he used in 1.1. There the negative phrasing (ad tempus, neque, neque, non, non longa) seemed to sweep aside instances of impure republican or un-republican rule disguising the fact that through these examples we are actually being presented with the main theme of the Annales: dominatio. ${ }^{12}$ In 1.16.1 it is again the negative phrases nullis novis causis, nisi quod mutatus princeps which, on the surface, disguise the fact that it is exactly this one new factor that changes the implications of a 'normal' (nullis novis causis) mutiny in the legions, and which calls for a penetrating study of this mutiny. The importance of the phrase mutatus princeps is reinforced by Percennius' repetition of the same idea in 1.17.1: novum et nutantem adhuc principem. This also provides us with an early illustration of how everything surrounding the succession will become an important catalyst for mobilizing the armies in the future, especially in the year 69 .

In 1.16.2 Tacitus gives us a glimpse of the psyche of Iunius Blaesus (1.16.2): $o b$ iustitium aut gaudium intermiserat solita munia. Once again he puts his finger on an aspect that gained great importance during the chaos of the year of the four emperors: the motives and the allegiance of commanders in the army, which are always uncertain and treacherous because they are often motivated by personal ambition. ${ }^{13}$ The next concise sentence in 1.16.2 is a sobering probe into the mens exercituum, and an introduction to the dramatic narration of the mutiny. The choice of words in lascivire and discordare (1.16.2) heightens the dramatic level of the narrative, highlighting the volatile nature of the force that is examined here. The troops are further characterized as fickle (pessimi cuiusque sermonibus praebere aures), self-interested (luxum et otium cupere) and undisciplined (disciplinam et laborem aspernari). These are exactly the factors which were exploited in 69 when self-interest and immediate gratification overrode any feelings for the common good or of patriotism. It becomes clear that the dramatization in 1.16-30 cannot be seen as an end in itself. It merely illustrates in the most appropriate way possible the nature of the potent force Tacitus wishes to draw our attention to, and with this, the dramatic implications of a seemingly trivial event.

12 See Kotzé 1990:47-48 for full analysis.

13 Goodyear (1972:198) thinks Tacitus might be implying that Blaesus' personal ambition is the real motive for his actions. 
2.4 Contrast, symmetry, parallelism and verbal echoes: the function of the comparison

In a text as dense and poetic as Tacitus' Annales, it is difficult to imagine that the group of words in 1.16 echoing the first chapters of the Annales is there by accident. On the first level there are of course words referring to the onset of the Pannonian mutiny (mutatus princeps and fine Augusti et initiis Tiberii auditis, 1.16.1-2) and indicating the obvious point of comparison between the two sections: the two sets of events described take place at more or less the same time and are reactions to the same thing. But it is the presence of rerum urbanarum status, ex civili bello spem, $o b$ iustitium aut gaudium and luxum et otium cupere (1.16.1-2), all in close proximity to the first mentioned words, which constitutes a cluster of words that alerts the reader to the possibility of a deeper level of comparison between the new section (1.16-30) and the previous one (1.1-15).

In the light of this context rerum urbanarum status will more probably recall 1.2.2: neque provinciae illum rerum statum abnuebant, a set of circumstances which represent the full force of Augustus' relentless quest to gain control in the Roman world (illum referring back to the loaded 1.2.1) and the means by which he succeeded to trap everyone, dulcedo otii. Thus the very negative way in which Tacitus has painted actions and reactions in Rome during Augustus' rise to power as well as immediately after his death is vividly recalled. Further the clause in modum servorum oboedirent in 1.17.1 reinforces the awareness of the words ruere in servitium of 1.7.1. The phrase ob iustitium aut gaudium (1.16.2) seems to recall lacrimas, gaudium, questus, adulationem miscebant of 1.7.1 in choice of words and its apparently contradictory character.

The question arises whether Tacitus intends to comment on the behaviour of people (mainly those from the senatorial class) in Rome by showing us the completely different type of behaviour of the soldiers. The actions of the senatorial class in Rome, in particular, have been depicted as unambiguously despicable. One could call the pervading servility, fear and falseness, as drawn by Tacitus, the characteristics of the group psychology of the consules, patres and eques. With this can be compared the mass psychology of the legions in Pannonia, which is characterized by the opposite of these undesirable qualities: insubordination, fearlessness (to a certain degree) and thorough (if foolish) directness. Such contrast, symmetry and parallelism, together with striking verbal echoes, make it certain that Tacitus intends his reader to see $1.16-30$ as a complement to and further commentary on 1.1-15. I feel that Tacitus momentarily entertains the possibility that the common soldiers actually possessed the ability to overcome the sickness of servitium, illustrated in 1.1-15.

This conflicts with the widely held notion that Tacitus' perspectives are inescapably bound to the senatorial view of life with its accompanying absolute disdain for people from the lower classes. In such a context a comparison of this kind (showing the soldiers in a more favourable light) would be improbable. But McCulloch's article (1991) may be cited as a reinforcement of my argument. In his 
chapter on history and metaphysical principles, McCulloch (1991:2938-2941) argues that although various scholars have succeeded in finding evidence to connect Tacitus with specific philosophical positions, they have

failed to realize that Tacitus was the ultimate skeptic, one who could never enthusiastically subscribe to any single philosophical/religious position. And we would be naive to believe that Tacitus himself ... did not see the apparent contradictions in his work.

He contends that what Tacitus does, is sometimes "(to marvel) at certain fascinating possibilities, then (to revert) almost instantaneously back to his normal skepticism."14 It is my view that this is exactly what Tacitus does in his description of how the soldiers react during the course of the Pannonian mutiny.

Let us take a closer look at some of the contrasts to be discerned between the first two sections of the Annales. Ann. 1.1-15 shows the utter baseness of the behaviour of the senatorial classes during Augustus' rise to power, during his reign $(1.2,1.4)$ and immediately after Tiberius' succession $(1.7,1.11-15) .15$ The way the legions in Pannonia are described illustrates clearly that they are the lower classes. They are irrepressible, fickle, noisy and interested in immediate advantage only, as the historical infinitives vividly bring to the fore: lascivire, discordare, (auris) praebere, (luxum et otium) cupere, (disciplinam) aspernari. However, in a sense the very fact that these people are not inactive and that their actions are direct and genuine must be seen in a positive light by the reader who has been almost brainwashed by 1.1-15 to hate the inertia of the people in Rome.

There is also the more direct contrast implied in 1.17.1 where Percennius' question (cur ... in modum servorum oboedirent) shows that he can appeal to a pride and fierceness that no longer exist in the senators in Rome. What is more, Percennius assumes that these people can be shaken out of their ignavia and he succeeds in doing so. He unleashes an active force of opposition to an imposed and unpopular system (adstrepebat, agitaverit, congerunt, extruunt). These actions have a psychological effect: superbire miles. This could be taken as the consequence of another negative character trait of the soldiery, but against the background of everything that has gone before, these words also tend to attain a positive connotation: the soldiers, in contrast with the senators, are proud, not servile. Paradoxically, it is the soldiers' feeling of self importance that contains the seeds which would make them not the answer to the sickness of servitium but the dangerous force they were to become in 69 . It is only the intervention of chance (1.28) which allows this force to be contained for the time being. The reader knows that he has been shown a first glimpse of a force which can eventually lead to a catastrophic series of events like those of A.D. 69.

14 I think it is this elusiveness in Tacitus' work which also motivates Walker's remark (1952:10):

"In Tacitus we may too easily find what we have looked for."

15 I have, however, shown (Kotze 1990) that the reader's sympathy is sollicited by the atmosphere Tacitus creates in the first 15 chapters of the Annales and within which these actions take place. 


\section{Conclusion}

The article has shown that in Ann. 1.16-30 Tacitus has not compromised 'historical truth' for the sake of 'artistic convenience'. That to a large degree the ratio and causae of 69 could be traced back to an event as trivial as the Pannonian mutiny, must have been a dramatic discovery for Tacitus. But the great dissimulator does not spell this out to his audience. He presents the dramatic discovery in a dramatic form and attains a perfect marriage of form and content.

\section{BIBLIOGRAPHY}

Goodyear, F R D 1972. The Annals of Tacitus. Vol, 1: Books 1-6. Cambridge: Cambridge University Press.

Heubner, H (ed.) 1983. P. Cornelii Taciti libri qui supersunt. Vol. 1. Stuttgart: Teubner.

Kotzé, A 1990. Tacitus se Annales 1.1-15: 'n Vertelkundige analise. M.A. thesis, University of Stellenbosch.

Leeman, A D 1973. Structure and Meaning in the Prologues of Tacitus. YClS 23, 169-208.

Leeman, A D 1974. De functie van de dramatisering bij Tacitus. Lampas 7, 368377.

Martin, R H 1990. Structure and Interpretation in the 'Annals' of Tacitus. ANRW II.33.2, 1500-1581.

McCulloch, H Y 1991: The Historical Process and Theories of History in the 'Annals' and 'Histories' of Tacitus. ANRW II.33.4, 2928-2948.

Miller, N P (ed.) 1959. Tacitus. Annals Book 1. London: Methuen.

Schmitt, H H 1958. Der Pannonische Aufstand des Jahres 14 n.Chr. und der Regienungsantritt des Tiberius. Historia 7, 378-383.

Walker, B 1952. The Annals of Tacitus: A Study in the Writing of History. Manchester: Manchester University Press.

Von Albrecht, M 1988. Die Gedankenwelt des Tacitus zwischen Tradition und Zukunf. $A U$ 31, 54-64. 